\title{
IMPLEMENTASI KEBIJAKAN PELAYANAN ADMINISTRASI BERBASIS SISTEM APLIKASI E-OFFICE PADA UNIT LAYANAN ADMINISTRASI PEMERINTAH PROVINSI SULAWESI UTARA
}

\author{
Karen Betsy Linelejan \\ Institut Pemerintahan Dalam Negeri (IPDN), Jatinangor \\ Email: Karen.bl@gmail.com
}

\begin{abstract}
Abstrak
Tujuan dari penelitian ini adalah untuk mengetahui bagaimana implementasi kebijakan pelayanan administrasi berbasis sistem aplikasi E-Office pada Unit Layanan Administrasi Pemerintah Provinsi Sulawesi Utara, faktor-faktor yang mendukung dan menghambat dalam pelaksanaan kebijakan, serta upaya yang dilakukan untuk mengatasi hambatan. Metode penelitian yang digunakan adalah metode penelitian deskriptif dengan pendekatan induktif. Adapun teknik pengumpulan data yang digunakan dalam penelitian ini berupa observasi, wawancara, dan dokumentasi. Implementasi kebijakan pelayanan administrasi berbasis sistem aplikasi E-Office pada Unit Layanan Administrasi Pemerintah Provinsi Sulawesi Utara masih belum berjalan dengan baik karena faktor sumber daya dan struktur birokrasi yang belum berjalan dengan baik. Adapun permasalahan yang terjadi yaitu masih terdapat pegawai yang kurang paham dengan sistem E-Office yang ada, tingkat pendidikan pegawai yang mayoritasnya adalah SMA dan masih terdapat juga yg tingkat pendidikannya SMP, masalah yang terkait dengan Standar Prosedur Operasional, dimana masih terjadi keterlambatan dalam penanganan berkas, serta terkait pelayanan surat masuk biro-biro yang belum dapat dilaksanakan karena sistem aplikasi E-Office yang bermasalah.
\end{abstract}

Kata Kunci: Implementasi Kebijakan, Pelayanan Administrasi, E-Office.

\begin{abstract}
The purpose of this study is to find out how the implementation of administrative service policies based on the E-Office application system at the North Sulawesi Provincial Government Administration Service Unit, the factors that support and hinder the implementation of policies, as well as the efforts made to overcome obstacles. The research method used is descriptive research method with an inductive approach. The data collection techniques used in this study were in the form of observation, interviews, and documentation. The implementation of administrative service policies based on the E-Office application system at the Administrative Service Unit of the North Sulawesi Provincial Government is still not going well due to resource factors and bureaucratic structures that have not been running well. The problems that occur are that there are still employees who do not understand the existing E-Office system, the level of education of employees whose majority is high school and there are still junior high school education levels, problems related to Standard Operating Procedures, where there are still delays in handling files. , as well as related to the service of incoming mail for bureaus which cannot be implemented because of the problematic E-Office application system.
\end{abstract}

Keywords: Policy Implementation, Administrative Services, E-Office. 


\section{A. PENDAHULUAN}

Pemerintah Daerah dalam hal ini Pemerintah Provinsi Sulawesi Utara terdiri dari beberapa instansi yang bertugas untuk melaksanakan pelayanan publik, dimana salah satunya adalah Biro Umum Sekretariat Daerah Provinsi Sulawesi Utara. Di Biro Umum sendiri terdapat satu unit layanan yang bertugas untuk melaksanakan pelayanan publik dalam hal ini pelayanan administratif, yakni Unit Layanan Administrasi (ULA) yang kedudukannya diatur dalam Peraturan Gubernur Nomor 3 Tahun 2020 tentang Perubahan Atas Peraturan Gubernur Sulawesi Utara Nomor 45 Tahun 2019 Tentang Kedudukan, Susunan Organisasi, Tugas dan Fungsi Serta Tata Kerja Sekretariat Daerah Provinsi Tipe A Provinsi Sulawesi Utara. Unit Layanan Administrasi (ULA) kemudian dibentuk pada tahun 2018 dengan maksud untuk menghadirkan suatu unit layanan adiministrasi yang berbasis teknologi, terintegrasi satu pintu, dengan memanfaatkan aplikasi E-Office, serta ditunjang dengan sarana prasarana dan aparatur yang memadai, sehingga memudahkan dan mempercepat pelayanan administrasi di lingkungan Pemerintah Provinsi Sulawesi Utara. Berdasarkan Surat Keputusan Gubernur Sulawesi Utara Nomor 435 Tahun 2018 tentang Standar Prosedur Operasional Unit Layanan Administrasi (ULA), secara garis besar ULA melayani 3 jenis pelayanan administrasi yang terbagi atas pelayanan surat masuk (ditujukan ke pimpinan dan ke biro-biro), pelayanan surat keluar/pengajuan tata naskah dinas, dan pelayanan ekspedisi.

Dengan berbagai penjelasan diatas mengenai pelayanan di Unit Layanan Administrasi (ULA), pada kenyataannya ULA masih menghadapi permasalahan-permasalahan dalam proses implementasinya. Diketahui bahwa berdasarkan observasi di lapangan, Sistem pelayanan di Unit Layanan Administrasi (ULA) walaupun sudah menggunakan sistem aplikasi E-Office tetap saja membutuhkan waktu yang lama dalam proses penyelesaian karena harus melewati SPO dengan alur birokrasi yang cukup panjang; Untuk penandatanganan surat, belum sesuai standar waktu yang ditetapkan dalam SPO, karena terkadang dibutuhkan waktu lebih dari satu minggu setelah surat diajukan ke ULA; Sistem aplikasi E-Office untuk surat masuk biro-biro masih bermasalah dan belum bisa dioperasikan; Sering terjadi keterlambatan jaringan pada sistem aplikasi E-Office yang mengakibatkan data tidak dapat diakses dengan cepat, dan data harus diinput secara manual pada buku agenda; Surat yang masuk melalui sistem aplikasi E-Office masih belum berbasis less paper, karena masih di disposisikan secara manual dengan menggunakan kertas, kemudian surat yang sudah di disposisi oleh pimpinan masih dikirimkan kepada penerima surat melalui proses manual dengan menggunakan jasa ekspedisi; Sistem Aplikasi E-Office di ULA masih bersifat lokal, dan belum terintegrasi dengan seluruh Perangkat Daerah di lingkup Pemprov. Sulawesi Utara.

Berdasarkan uraian latar belakang masalah, Peneliti mengidentifikasi permasalahan sebagai berikut:

1. Sistem pelayanan di Unit Layanan Administrasi (ULA) walaupun sudah menggunakan sistem aplikasi E-Office tetap saja membutuhkan waktu yang lama dalam proses penyelesaian karena harus melewati SPO dengan alur birokrasi yang cukup panjang;

2. Untuk penandatanganan surat, belum sesuai standar waktu yang ditetapkan dalam SPO, karena terkadang dibutuhkan waktu lebih dari satu minggu setelah surat diajukan ke ULA; 
3. Sistem aplikasi E-Office untuk surat masuk biro-biro masih bermasalah dan belum bisa dioperasikan;

4. Sering terjadi keterlambatan jaringan pada sistem aplikasi E-Office yang mengakibatkan data tidak dapat diakses dengan cepat, dan data harus diinput secara manual pada buku agenda;

5. Surat yang masuk melalui sistem aplikasi E-Office masih belum berbasis less paper, karena masih di disposisikan secara manual dengan menggunakan kertas, kemudian surat yang sudah di disposisi oleh pimpinan masih dikirimkan kepada penerima surat melalui proses manual dengan menggunakan jasa ekspedisi;

6. Sistem Aplikasi E-Office di ULA masih bersifat lokal, dan belum terintegrasi dengan seluruh Perangkat Daerah di lingkup Pemprov. Sulawesi Utara.

Mengacu pada perumusan masalah penelitian, maka tujuan penelitian ini adalah untuk mengetahui bagaimana hasil implementasi kebijakan, apa saja faktor pendukung dan penghambat, serta bagaimana upaya yang dilakukan untuk mengatasi hambatan dalam proses Implementasi Kebijakan Pelayanan Berbasis Aplikasi E-Office pada Unit Layanan Administrasi Pemerintah Provinsi Sulawesi Utara.

\section{B. METODE}

Penelitian ini menggunakan jenis penelitian kualitatif deskriptif dengan analisis data secara induktif (Moleong, 2008:6). Penelitian kualitatif didasarkan pada upaya membangun pandangan secara rinci, dibentuk dengan kata-kata, gambaran holistik dan rumit. Peneliti melakukan analisis dengan menggunakan model implementasi Edward III, karena keempat variabelnya beroperasi secara simultan dan berinteraksi satu sama lain untuk membantu atau bersifat merintangi implementasi kebijakan.

Dalam penelitian ini, teknik pengumpulan data yang digunakan berupa teknik wawancara, observasi, studi dokumentasi. Teknik analisis data yang digunakan dalam penelitian ini mengikuti Alur Miles \& Huberman yang terdiri dari reduksi data, penyajian data, dan verifikasi/menarik kesimpulan (conclusion drawing) (Sugiyono, 2011:246). Ketiga teknik analisis data yang dikemukakan oleh Miles dan Huberman tersebut dilakukan pada semua tahap dalam proses penelitian kualitatif, yaitu pada tahap deskripsi, fokus, dan seleksi.

\section{HASIL DAN PEMBAHASAN}

\section{Implementasi Kebijakan Pelayanan Administrasi Berbasis Sistem Aplikasi E- Office pada Unit Layanan Administrasi Pemerintah Provinsi Sulawesi Utara}

a. Komunikasi

Terdapat tiga hal yang harus diperhatikan dalam komunikasi, yaitu transmisi, kejelasan, dan konsistensi. Dalam indikator transmisi, menghendaki agar penyaluran atau penyampaian informasi dari petugas Unit Layanan Administrasi (ULA) kepada pegawai dan masyarakat dapat dipahami dengan jelas dan dapat dimengerti apa yang menjadi maksud, tujuan, serta bagaimana tata cara pelaksanaannya. Berdasarkan hasil penelitian, proses komunikasi dalam hal transmisi atau penyaluran informasi terkait Kebijakan Pelayanan Administrasi Berbasis Sistem Aplikasi E-Office pada Unit Layanan Administrasi secara umum telah dilaksanakan oleh para petugas pelayanan di ULA kepada pegawai dan 
masyarakat. Penyampaian disampaikan secara langsung melalui sosialisasi dan publikasi melalui media elektronik.

Komunikasi yang ditransmisikan kepada pelaksana maupun penerima kebijakan harus diterima dengan jelas dan tidak membingungkan sehingga dapat diketahui dengan jelas apa yang menjadi maksud, tujuan dan sasaran pelaksanaan kebijakan tersebut. Kejelasan petunjuk dalam pelaksanaan Kebijakan Pelayanan Administrasi Berbasis Sistem Aplikasi EOffice ini ditandai dengan adanya Standar Prosedur Operasional Unit Layanan Administrasi (ULA) yang jelas.

Dalam Pelaksanaan Kebijakan Pelayanan Administrasi Berbasis Sistem Aplikasi EOffice pada umumnya sudah dilakukan secara konsisten, dapat dilihat dari produk hukum yang telah dibentuk oleh pemerintah daerah, yang berisi berbagai petunjuk pelaksanaan pelayanan, serta dilihat juga dari tim pelaksana kebijakan yang selalu konsisten dalam melaksanakan tugas pelayanan dan melakukan sosialisasi kepada pegawai ataupun masyarakat yang datang di ULA.

b. Sumberdaya

Indikator kedua dari Implementasi Kebijakan Pelayanan Administrasi Berbasis Sistem Aplikasi E-Office pada Unit Layanan Administrasi (ULA) Pemerintah Provinsi Sulawesi Utara yaitu ketersediaan sumberdaya, yang terdiri dari Sumber Daya Manusia,Sumber Daya Informasi, Sumber Daya Kewenangan, dan Sumber Daya Fasilitas.

Sumber Daya Manusia yang ada di Unit Layanan Administrasi (ULA) merupakan pegawai/staf yang memiliki kompetensi, keahlian maupun keterampilan dalam melakukan tugas sesuai tupoksi pelaksanaan Kebijakan Pelayanan Administrasi Berbasis Sistem Aplikasi E-Office. Jumlah pegawai yang kurang dapat menyebabkan pekerjaan tidak berjalan efektif. Selain jumlah pegawai, tingkat pendidikan pegawai juga tentu mempengaruhi kualitas sumber daya manusia yang dihasilkan. Menurut data kepegawaian tahun 2020, pegawai/staf di ULA, tingkat pendidikan mayoritasnya adalah SMA bahkan ada yang SMP. Selain itu, masih banyak juga pegawai yang tidak bisa mengoperasikan komputer, apalagi dengan Sistem Aplikasi E-Office yang ada.

Sumber Daya Informasi juga merupakan indikator yang penting dalam pelaksanaan kebijakan. Hal pertama yang harus diketahui oleh implementor adalah informasi mengenai bagaimana melaksanakan suatu kebijakan. Di ULA sendiri dapat dilihat bahwa, untuk sumber daya informasi sudah sangat jelas, sehingga dapat dimengerti oleh setiap pihak, baik pelaksana pelayanan maupun penerima layanan.

Sumber daya lain yang penting dalam pelaksanaan kebijakan adalah wewenang untuk menentukan bagaimana suatu kebijakan dilakukan. Berdasarkan hasil pengamatan Peneliti di lapangan, dapat melihat bahwa setiap petugas pelayanan sudah mengetahui apa yang menjadi kewenangan mereka, dan apa yang menjadi kewenangan atasan.

Fasilitas sebagai salah satu sumberdaya yang penting dalam implementasi. Fasilitas yang diperlukan untuk melaksanakan suatu program harus terpenuhi terlebih dahulu kemudian diikuti oleh pelaksanaan program yang efektif pula. Fasilitas yang disediakan untuk kelancaran implementasi dapat berupa dana dan sarana/peralatan sesuai dengan kebijakan yang dibentuk. Berdasarkan pengamatan Peneliti di lapangan, fasilitas di ULA sendiri sudah sangat memadai, karena terdapat fasilitas yang lengkap dan juga dengan ruangan yang nyaman baik bagi petugas pelayanan maupun para penerima layanan. 


\section{c. Disposisi}

Disposisi atau sikap pelaksana kebijakan terbagi menjadi dua yakni pengangkatan birokrat dan insentif. Unit Layanan Administrasi merupakan bagian dari birokrasi yang ada di Pemerintah Provinsi Sulawesi Utara. Dalam dunia birokrasi tentu saja ada birokratbirokrat yang ditunjuk untuk menempati jabatan/posisi tertentu, begitu pula dengan di ULA. Pegawai yang terlibat langsung dalam pelaksanaan Pelayanan Administrasi Berbasis Sistem Aplikasi E-Office di ULA diangkat dan dipilih berdasarkan kemampuan dan kompetensi sesuai dengan jabatan yang dibutuhkan di ULA. Berdasarkan hasil pengamatan Peneliti di lapangan, para pejabat yang ditempatkan di ULA sudah tepat dan mereka sangat profesional dalam melaksanakan tugas, mereka paham benar tentang apa yang harus dilakukan untuk memajukan ULA.

Disposisi juga dipengaruhi oleh insentif atau keuntungan-keuntungan tertentu sebagai salah satu bentuk reward sehingga menjadi faktor pendorong yang membuat para implementor melaksanakan perintah dengan baik. Terkadang dengan penghasilan yang terbatas membuat para pelaksana kebijakan tidak bekerja dengan baik sehingga pemberian insentif menjadi salah satu cara untuk menambah motivasi kerja para pelaksana kebijakan. Pemerintah Provinsi Sulawesi Utara dalam hal ini Gubernur dan Wakil Gubernur Sulawesi Utara, setiap tahunnya memberikan kenaikan insentif atau yang dikenal dengan Tunjangan Berbasis Kinerja (TBK) kepada setiap PNS di lingkungan Pemerintah Provinsi Sulawesi Utara. Selain itu kenaikan gaji juga berlaku untuk setiap pegawai THL di lingkungan Pemerintah Provinsi Sulawesi Utara, tak terkecuali pegawai-pegawai di Unit Layanan Administrasi Pemerintah Provinsi Sulawesi Utara.

\section{d. Struktur Birokrasi}

Terdapat dua karakteristik utama dari birokrasi, yaitu adanya Standard Operating Prosedures (SOPs) atau prosedur-prosedur dan fragmentasi. Berdasarkan hasil penelitian, terkait dengan Standar Prosedur Operasional, dimana masih terdapat permasalahan karena terkadang masih terjadi keterlambatan dalam penanganan berkas dalam hal ini membutuhkan waktu yang lama untuk bisa ditandatangani oleh pejabat terkait, selain itu untuk Standar Operasional Prosedur belum sepenuhnya terlaksana di ULA, karena ada satu sistem aplikasi yang bermasalah, yakni sistem aplikasi untuk pelayanan surat masuk biro-biro.

Fragmentasi yang berkaitan dalam Implementasi Kebijakan Pelayanan Administrasi Berbasis Sistem Aplikasi E-Office pada Unit Layanan Administrasi (ULA) Pemerintah Provinsi Sulawesi Utara adalah berupa kerjasama antar pihak Biro Umum dan pihak-pihak diluar biro umum. Menurut Kepala Sub Bagian Tata Usaha Pimpinan Dan Staf Ahli yang mengatakan bahwa pembentukan ULA melibatkan keterlibatan berbagai pihak sejak awal penggagasannya, yang terdiri dari: Biro Umum Setda Prov. Sulut, selaku penggagas dan penyusun formulasi ULA; Biro Organisasi Setda Prov. Sulut, membantu penyusunan dan perumusan SOP ULA; Biro Hukum Setda Prov. Sulut, membantu dalam perumusan dan penetapan SK Gubernur Nomor 435 tahun 2018, tentang SOP ULA; Dinas Kominfo Daerah, membantu dalam pemanfaatan Teknologi, pembangunan Website, penggunaan Hosting serta server Aplikasi ULA; BKD Provinsi, dukungan penempatan ASN berkompeten; Konsultan IT, pembuatan software aplikasi E-Office ULA; Gubernur, Wakil Gubernur dan Sekretaris Daerah Provinsi memegang peranan sangat penting dan mendasar dalam pembentukan ULA. Sejak digagas dan disampaikan secara langsung oleh Biro Umum selaku unit kerja terkait, 
pembentukan ULA didukung penuh, yang tergambar dengan Penetapan SK SOP ULA oleh Gubernur, dukungan penganggaran dalam APBD, monitoring langsung secara berkala, dan melaunching secara langsung ULA.

\section{Faktor Pendukung dan Penghambat Dalam Implementasi Kebijakan Pelayanan Administrasi Berbasis Sistem Aplikasi E-Office pada Unit Layanan Administrasi (ULA) Pemerintah Provinsi Sulawesi Utara}

Dalam setiap pelaksanaan suatu kebijakan, tentu saja terdapat faktor-faktor yang dapat menjadi pendukung, maupun penghambat dalam proses pengimplementasian kebijakan tersebut. Begitu juga dalam pengimplementasian Kebijakan Pelayanan Administrasi Berbasis Sistem Aplikasi E-Office pada Unit Layanan Administrasi (ULA) Pemerintah Provinsi Sulawesi Utara. Faktor pendukung dalam Implementasi Kebijakan Pelayanan Administrasi Berbasis Sistem Aplikasi E-Office Pada Unit Layanan Administrasi (ULA) Pemerintah Provinsi Sulawesi Utara ini adalah Sumber Daya yang ada. Adapun sumber daya yang dimaksud adalah sumber daya fasilitas dalam hal ini keuangan dan SDM/aparatur. Sumber daya keuangan karena jumlah insentif yang cukup besar untuk pegawai, serta dari segi fasilitas dan penganggaran ULA sudah cukup memadai. Selanjutnya yang menjadi faktor pendukung adalah sumber daya manusia atau aparatur. Hal ini cukup menarik karena faktor SDM bukan hanya menjadi masalah saja dalam proses implementasi kebijakan, namun juga bisa menjadi faktor pendukung, karena masih terdapat pegawai-pegawai yang memiliki kapasitas yang baik dalam hal pelayanan administrasi berbasis sistem E-Office, mereka adalah pegawai-pegawai yang berpendidikan tinggi, dan tentu saja menguasai tupoksi mereka sebagai petugas pelayanan di ULA. Faktor pendukung yang juga tak kalah penting yaitu berasal dari dukungan para penerima layanan atau masyarakat.

Sedangkan yang menjadi faktor penghambat ialah masih sering terjadi kesalahan teknis dalam sistem aplikasi E-Office, baik karena masalah jaringan, ataupun karena gangguan pada sistem aplikasi itu sendiri yang membuat sistemnya menjadi down bahkan tidak dapat dijalankan sama sekali. Jadi masih sering terjadi keterlambatan dalam penanganan surat-surat yang masuk. Hal lain yang juga menjadi faktor penghambat adalah masalah alur birokrasi yang dapat dibilang cukup panjang, sehingga terkadang dalam proses penyelesaian berkas membutuhkan waktu yang lama. Pada SPO ULA sendiri pun, pada tahap penandatangan berkas oleh Pejabat terkait memang tidak dicantumkan berapa lama waktu penyelesaian karena memang sampai saat ini, belum ada waktu yang pasti karena harus menyesuaikan dengan waktu Pejabat terkait.

\section{Upaya Yang Dilakukan Untuk Mengatasi Hambatan dalam Implementasi} Kebijakan Pelayanan Administrasi Berbasis Sistem Aplikasi E-Office pada Unit Layanan Administrasi (ULA) Pemerintah Provinsi Sulawesi Utara

Adapun upaya yang dilakukan untuk mengatasi hambatan-hambatan dalam implementasi kebijakan yakni sebagai berikut:

a. Pada saat jaringan lambat atau terjadi kesalahan pada sistem E-Office, upaya yang dilakukan adalah dengan segera memproses setiap surat yang masuk, diinput dengan cara manual menggunakan buku agenda, agar pelayanan penerimaan berkas tidak 
terhenti. Setelah sistem dan jaringan kembali normal, barulah data-data surat diinput ke sistem E-Office

b. Terus berupaya untuk memperbaiki sistem E-Office yang ada. Salah satunya dengan terus menganggarkan biaya maintenance sistem agar terus terjadi perubahanperubahan atau dapat diupdate dengan sistem yang baru, sesuai dengan saran dari konsultan IT yang bekerja sama dengan ULA. Bahkan untuk kedepannya telah ditargetkan peningkatan lebih lanjut kualitas layanan ULA, untuk ditumbuhkembangkan sesuai kebutuhan yang diamanatkan dalam e-government menuju smart Province, antara lain; integrasi secara online dengan seluruh perangkat daerah, aktualisasi e-surat, ekspedisi surat berbasis aplikasi dan GPS, bahkan tidak menutup kemungkinan, integrasi secara online dengan seluruh pemerintah kabupaten/kota di Sulawesi Utara.

c. Untuk mengatasi masalah keterlambatan dalam penandatangan berkas. Sebenarnya telah diusulkan untuk diadakannya sistem disposisi dan tanda tangan elektronik, agar para pejabat dapat lebih leluasa untuk melakukan disposisi atau bertanda tangan dari mana saja tanpa harus diruangan kerja. Namun hal tersebut membutuhkan sejumlah anggaran untuk dapat membuat sistem yang diinginkan, sedangkan untuk tahun 2020 dan tahun 2021 ini, untuk sementara anggaran masih difokuskan untuk mengatasi pandemi Covid 19, jadi rencana tersebut masih tertunda.

\section{KESIMPULAN}

Berdasarkan teori implementasi kebijakan yang dikemukakan oleh Edward III, bahwa suatu implementasi kebijakan dapat dikatakan berhasil apabila keempat faktor yang mempengaruhi implementasi kebijakan yaitu faktor komunikasi, sumber daya, disposisi, dan struktur birokrasi berjalan dengan baik. Sedangkan dalam Implementasi Kebijakan Pelayanan Administrasi Berbasis Sistem Aplikasi E-Office Pada Unit Layanan Administrasi (ULA) Pemerintah Provinsi Sulawesi Utara, dari keempat faktor yang mempengaruhi, masih terdapat dua faktor yang belum berjalan dengan baik, yaitu faktor sumber daya dan struktur birokrasi. Adapun faktor sumber daya yang dimaksud adalah sumber daya manusianya, dimana masih terdapat pegawai yang kurang paham dengan sistem E-Office yang ada. Selain itu tingkat pendidikan pegawai juga mayoritasnya adalah SMA dan masih terdapat juga yg tingkat pendidikannya SMP. Untuk faktor struktur birokrasi yang dimaksud adalah masalah yang terkait dengan Standar Prosedur Operasional, dimana masih terdapat permasalahan karena terkadang masih terjadi keterlambatan dalam penanganan berkas dalam hal ini membutuhkan waktu yang lama untuk bisa ditandatangani oleh pejabat terkait. Selain itu untuk SPO terkait pelayanan surat masuk biro-biro belum dapat dilaksanakan karena sistem aplikasi E-Office yang bermasalah. Jadi dapat disimpulkan bahwa Implementasi Kebijakan Pelayanan Administrasi Berbasis Sistem Aplikasi E-Office Pada Unit Layanan Administrasi (ULA) Pemerintah Provinsi Sulawesi Utara belum dapat dikatakan berhasil atau dengan kata lain belum sepenuhnya berjalan dengan baik.

Faktor pendukung dalam Implementasi Kebijakan Pelayanan Administrasi Berbasis Sistem Aplikasi E-Office Pada Unit Layanan Administrasi (ULA) Pemerintah Provinsi Sulawesi Utara ini adalah Sumber Daya yang ada. Adapun sumber daya yang dimaksud adalah sumber daya fasilitas dalam hal ini keuangan dan SDM/aparatur. Sumber daya 
keuangan karena jumlah insentif yang cukup besar untuk pegawai, serta dari segi fasilitas dan penganggaran ULA sudah cukup memadai. Selanjutnya yang menjadi faktor pendukung adalah sumber daya manusia atau aparatur. Hal ini cukup menarik karena faktor SDM bukan hanya menjadi masalah saja dalam proses implementasi kebijakan, namun juga bisa menjadi faktor pendukung, karena masih terdapat pegawai-pegawai yang memiliki kapasitas yang baik dalam hal pelayanan administrasi berbasis sistem E-Office, mereka adalah pegawaipegawai yang berpendidikan tinggi, dan tentu saja menguasai tupoksi mereka sebagai petugas pelayanan di ULA. Faktor pendukung yang juga tak kalah penting yaitu berasal dari dukungan para penerima layanan atau masyarakat. Sedangkan yang menjadi faktor penghambat ialah masih sering terjadi kesalahan teknis dalam sistem aplikasi E-Office, baik karena masalah jaringan, ataupun karena gangguan pada sistem aplikasi itu sendiri yang membuat sistemnya menjadi down bahkan tidak dapat dijalankan sama sekali. Jadi masih sering terjadi keterlambatan dalam penanganan surat-surat yang masuk. Hal lain yang juga menjadi faktor penghambat adalah masalah alur birokrasi yang dapat dibilang cukup panjang, sehingga terkadang dalam proses penyelesaian berkas membutuhkan waktu yang lama. Pada SPO ULA sendiri pun, pada tahap penandatangan berkas oleh Pejabat terkait memang tidak dicantumkan berapa lama waktu penyelesaian karena memang sampai saat ini, belum ada waktu yang pasti karena harus menyesuaikan dengan waktu Pejabat terkait.

Adapun upaya yang dilakukan untuk mengatasi hambatan-hambatan dalam implementasi kebijakan yakni sebagai berikut:

1. Pada saat jaringan lambat atau terjadi kesalahan pada sistem E-Office, upaya yang dilakukan adalah dengan segera memproses setiap surat yang masuk, diinput dengan cara manual menggunakan buku agenda, agar pelayanan penerimaan berkas tidak terhenti. Setelah sistem dan jaringan kembali normal, barulah data-data surat diinput ke sistem E-Office

2. Terus berupaya untuk memperbaiki sistem E-Office yang ada. Salah satunya dengan terus menganggarkan biaya maintenance sistem agar terus terjadi perubahanperubahan atau dapat diupdate dengan sistem yang baru, sesuai dengan saran dari konsultan IT yang bekerja sama dengan ULA. Bahkan untuk kedepannya telah ditargetkan peningkatan lebih lanjut kualitas layanan ULA, untuk ditumbuhkembangkan sesuai kebutuhan yang diamanatkan dalam e-government menuju smart Province, antara lain; integrasi secara online dengan seluruh perangkat daerah, aktualisasi e-surat, ekspedisi surat berbasis aplikasi dan GPS, bahkan tidak menutup kemungkinan, integrasi secara online dengan seluruh pemerintah kabupaten/kota di Sulawesi Utara.

3. Untuk mengatasi masalah keterlambatan dalam penandatangan berkas. Sebenarnya telah diusulkan untuk diadakannya sistem disposisi dan tanda tangan elektronik, agar para pejabat dapat lebih leluasa untuk melakukan disposisi atau bertanda tangan dari mana saja tanpa harus diruangan kerja. Namun hal tersebut membutuhkan sejumlah anggaran untuk dapat membuat sistem yang diinginkan, sedangkan untuk tahun 2020 dan tahun 2021 ini, untuk sementara anggaran masih difokuskan untuk mengatasi pandemi Covid 19, jadi rencana tersebut masih tertunda. 


\section{DAFTAR PUSTAKA}

Ardipandanto, A., \& Budiman, A. (2018). Dinamika Pelaksanaan Urusan di Bidang Persandian Pemerintah Daerah. Yayasan Pustaka Obor Indonesia.

Arikunto, S. (2010). Prosedur Penelitian Suatu Pendekatan Praktik. Jakarta: Rineka Cipta.

Bagoes, I. M. (2004. Filsafat Penelitian \& Metode Penelitian Sosial. Yogyakarta: Pustaka Belajar.

Gulo, W. (2007). Metodologi Penelitian. Jakarta: Gramedia Widiasarana Indonesia.

Irawan, P. (2004). Logika dan Prosedur Penelitian. Jakarta: STIA LAN Press.

Moleong, L. J. (2008). Metodologi Penelitian Kualitatif. Bandung: Remaja Rosdakarya.

Nurdiassa, A., Zulfikar, A., Rasyid, F., \& Wulandari, A. T. (2021). Implementasi Kebijakan

Smart City dalam Mewujudkan Makassar Kota Dunia. Journal of Public Administration and Government, 3(1), 37-46.

Sugiyono. (2011). Metode Penelitian Kuantitatif, Kualitatif dan $R \& B$. Bandung: Alfabeta.

Surat Keputusan Gubernur Sulawesi Utara Nomor 435 Tahun 2018 tentang Standar Prosedur Operasional Unit Layanan Administrasi (ULA).

Pane, T., Tulusan, F., \& Tampi, G. B. (2020). Efektivitas Unit Layanan Administrasi Dalam Pengelolaan Data di Sekretariat Daerah Provinsi Sulawesi Utara. Jurnal Administrasi Publik, 6(91).

Peraturan Gubernur Sulawesi Utara Nomor Nomor 3 Tahun 2020 tentang Perubahan Atas Peraturan Gubernur Sulawesi Utara Nomor 45 Tahun 2019 tentang Kedudukan, susunan organisasi, tugas dan fungsi serta tata kerja sekretariat daerah provinsi Tipe A Provinsi Sulawesi Utara.

Wahyudi, R., Mursalin, A., \& Sagala, I. (2020). Implementasi E-Government di Kejaksaan Tinggi Provinsi Jambi (Doctoral dissertation, UIN Sulthan Thaha Saifuddin Jambi).

Yunita, N. P. (2018). Kondisi Terkini Perkembangan e-Government di Indonesia: Praktik Pemerintah dan Persepsi Publik (Master's thesis, Universitas Islam Indonesia). 